\title{
Omega-3 and omega-6 PUFAs induce the same GPR120-mediated signalling events, but with different kinetics and intensity in Caco-2 cells
}

Kaia Mobraten ${ }^{1 *}$, Trude M Haug ${ }^{2}$, Charlotte R Kleiveland ${ }^{1,3}$ and Tor Lea ${ }^{1}$

\begin{abstract}
Background: Omega-3 PUFAs are known to have anti-inflammatory properties, and different mechanisms are involved. GPR120 is a G-protein coupled receptor that has recently received attention because of its anti-inflammatory signalling properties after binding omega-3 PUFAs. However, both omega-3 and omega-6 PUFAs are natural GPR120 ligands. The aim of this study was to study possible differences in GPR120-mediated signalling events after treatment with different long-chain PUFAs in intestinal epithelial cells. We also investigated possible GPR120-mediated anti-inflammatory effects of different long-chain PUFAs that may be relevant in the understanding of how dietary PUFAs influence inflammatory responses in inflammatory diseases such as IBD.
\end{abstract}

Methods: We used Caco-2 cells as a model system to study GPR120-mediated signalling events because we found this cell line to express GPR120, but not GPR40, another plasma membrane receptor for medium- and long chain fatty acids. Increase in cytosolic $\mathrm{Ca}^{2+}$ concentration, activation of MAP kinase ERK1/2 and the inhibition of IL-1 $\beta$ induced NF-KB activity were studied to reveal potential differences in the activation of GPR120 by the omega-3 PUFAs eicosapentaenoic acid (EPA) and docosahexaenoic acid (DHA) and the omega-6 PUFA arachidonic acid (AA)

Results: We found that EPA, DHA and AA enhanced the cytosolic concentration of the second messenger $\mathrm{Ca}^{2+}$ with the same efficiency, but with different kinetics. Both omega-3 and omega-6 PUFAs activated MAP kinase ERK1/2, but differences regarding kinetics and intensity were also observed in this pathway. ERK1/2 activation was shown to be dependent upon EGFR and Raf-1. We further investigated the ability of EPA, DHA and AA to inhibit NF-KB activity in Caco-2 cells. All PUFAs tested were able to inhibit IL-1 $\beta$ induced breakdown of IKBa after binding to GPR120, but with different potency.

Conclusions: Our results show that EPA, DHA and AA elicit the same signalling events, but with different kinetics and efficiency through GPR120 in Caco-2 cells. We show, for the first time, that both omega-3 and omega-6 PUFAs inhibit NF-kB activation in intestinal epithelial cells. Our results may be important for understanding how dietary PUFAs influence inflammatory processes relevant in delineating effects of PUFAs in the treatment of IBD.

Keywords: Polyunsaturated fatty acids (PUFAs), GPR120 Caco-2 cells

\footnotetext{
* Correspondence: kaia.mobraten@umb.no

'Department of Chemistry, Biotechnology and Food Science, University of Life Sciences, Post box 5003, NO-1430 Aas, Norway

Full list of author information is available at the end of the article
} 


\section{Introduction}

During digestion, dietary triglycerides are cleaved into monoglycerides and free fatty acids (FFAs). These FFAs are important nutrients in the daily energy intake, but they also act as signalling molecules mediating their effects through both nuclear- and plasma membrane receptors. Four FFA-binding G-protein coupled receptors (GPCRs) have been characterized, which bind FFAs with different chain lengths. FFAR2 (GPR43) and FFAR3 (GPR41) are activated by short-chain fatty acids (SCFAs), mainly acetate, propionate and butyrate, produced in colon by bacterial fermentation of indigestible carbohydrates $[1,2]$. GPR120 together with GPR40 (FFAR1) are activated by saturated and unsaturated medium- (C6-C12) and longchain (C14-24) FFAs [3-6]. GPR40 is most abundantly expressed in pancreatic $\beta$-cells where it contributes to the regulation of insulin secretion $[4,7,8]$. GPR40 and GPR120 are both expressed in the gastrointestinal tract, where they regulate digestion through the secretion of cholecystokinin (CCK). In addition, they aid in insulin secretion by stimulating the release of the incretin hormones, glucagon-like peptide 1 (GLP-1) and glucose-dependent insulinotropic polypeptide (GIP) $[4,6,9,10]$.

Polyunsaturated fatty acids (PUFAs) are principally divided into the omega- 6 and the omega- 3 families. Linoleic acid (LA) and arachidonic acid (AA) are essential omega- 6 fatty acids and $\alpha$-linolenic acid (ALA), eicosapentaenoic acid (EPA) and docosahexaenoic acid (DHA) are essential omega-3 fatty acids. Omega-3 fatty acids are generally considered anti-inflammatory, and different mechanisms are described. Incorporation of omega-3 fatty acids in the cell membrane lowers the content of $\mathrm{AA}$, and thereby the substrate for synthesis of AA-derived eicosanoids, which are generally considered more proinflammatory than eicosanoids derived from EPA.

The transcription factor NF- $\mathrm{KB}$ is a key regulator of inflammation, and activation of NF- $\mathrm{kB}$ plays a key role in the initiation and perpetuation of the inflammatory diseases, including Crohn's disease and Ulcerative colitis, collectively named inflammatory bowel diseases (IBDs). Omega-3 fatty acids reduce NF- $\mathrm{KB}$ mediated inflammatory signals, an effect that has been linked to the activation of peroxisome proliferator activated receptor $-\gamma$ (PPAR- $\gamma$ ) and GPR120 [11-13]. Because of its antiinflammatory properties, dietary supplementation of omega-3 PUFAs has been recommended in the treatment of patients with IBD. Animal studies have demonstrated beneficial effects from omega-3 PUFAs in the treatment of IBD [14-19], but results from human clinical trials are inconsistent with no clear evidence of efficacy [20]. However, in vitro studies have shown that omega-3 PUFAs exert anti-inflammatory effects in intestinal epithelial cells $[21,22]$. Thus, there is a need to know more about how omega-3 PUFAs interact with intestinal epithelial cells in order to understand how omega-3 PUFAs may have beneficial effects and to optimize the use of omega-3 PUFAs, in the treatment of IBD.

Omega-3 and omega-6 PUFAs are both natural ligands of GPR120, but recent review articles refer to its antiinflammatory properties upon binding omega-3 PUFAs only [23,24]. GPR120 is expressed in the gastrointestinal tract, and the aim of this study was to elucidate signalling pathways activated by omega- 3 and omega- 6 PUFAs in intestinal epithelial cells. Caco-2 cells were used as a model system to study GPR120 signalling in intestinal epithelial cells. We further investigated the ability of both omega-3 and omega- 6 PUFAs to inhibit NF- $\mathrm{kB}$ activation after binding to GPR120 on Caco-2 cells.

\section{Results}

PCR

PUFAs are natural ligands of GPR120 and GPR40. mRNA for GPR120 was detected in normal tissue both from ileum and colon, and in the Caco-2 cell line (Figure 1). On the other hand, GPR40 was only detected in the ileum and colon, which made Caco- 2 cells a suitable system to specifically study PUFA-induced activation of GPR120.

\section{PUFAs elevate the cytosolic $\mathrm{Ca}^{2+}$ concentration}

Studies describing GPR120 signalling in different cellular systems, including intestinal epithelial cells, have revealed that GPR120 is coupled to $G_{\alpha q}[6,10,25]$. However, GPR120 has not been described in Caco-2 cells previously. Since $\left[\mathrm{Ca}^{2+}\right]_{\mathrm{i}}$ can be used as a measure of $\mathrm{G}_{\alpha q}$ activity, we investigated whether stimulation with EPA, DHA and AA was able to enhance $\left[\mathrm{Ca}^{2+}\right]_{\mathrm{i}}$ in Caco-2 cells.

Figure 2 shows that treatment with $200 \mu \mathrm{M}$ EPA, DHA or AA transiently increased $\left[\mathrm{Ca}^{2+}\right]_{\mathrm{i}}$ in Caco-2 cells. During treatment with the different PUFAs, the maximum increase of F360/F380, which monitors $\left[\mathrm{Ca}^{2+}\right]_{i}$ were $52.2 \pm 2.4 \%$ compared to untreated cells with EPA, $48.9 \pm 1.8 \%$ with DHA, and $51.5 \pm 2.6 \%$ with AA, and there were no significant differences between the responses to the three fatty acids (Figure 2B). However,

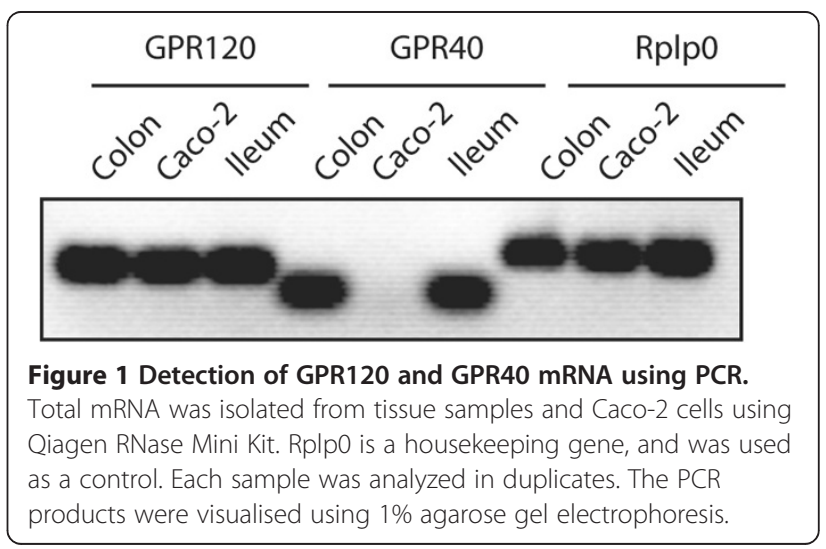




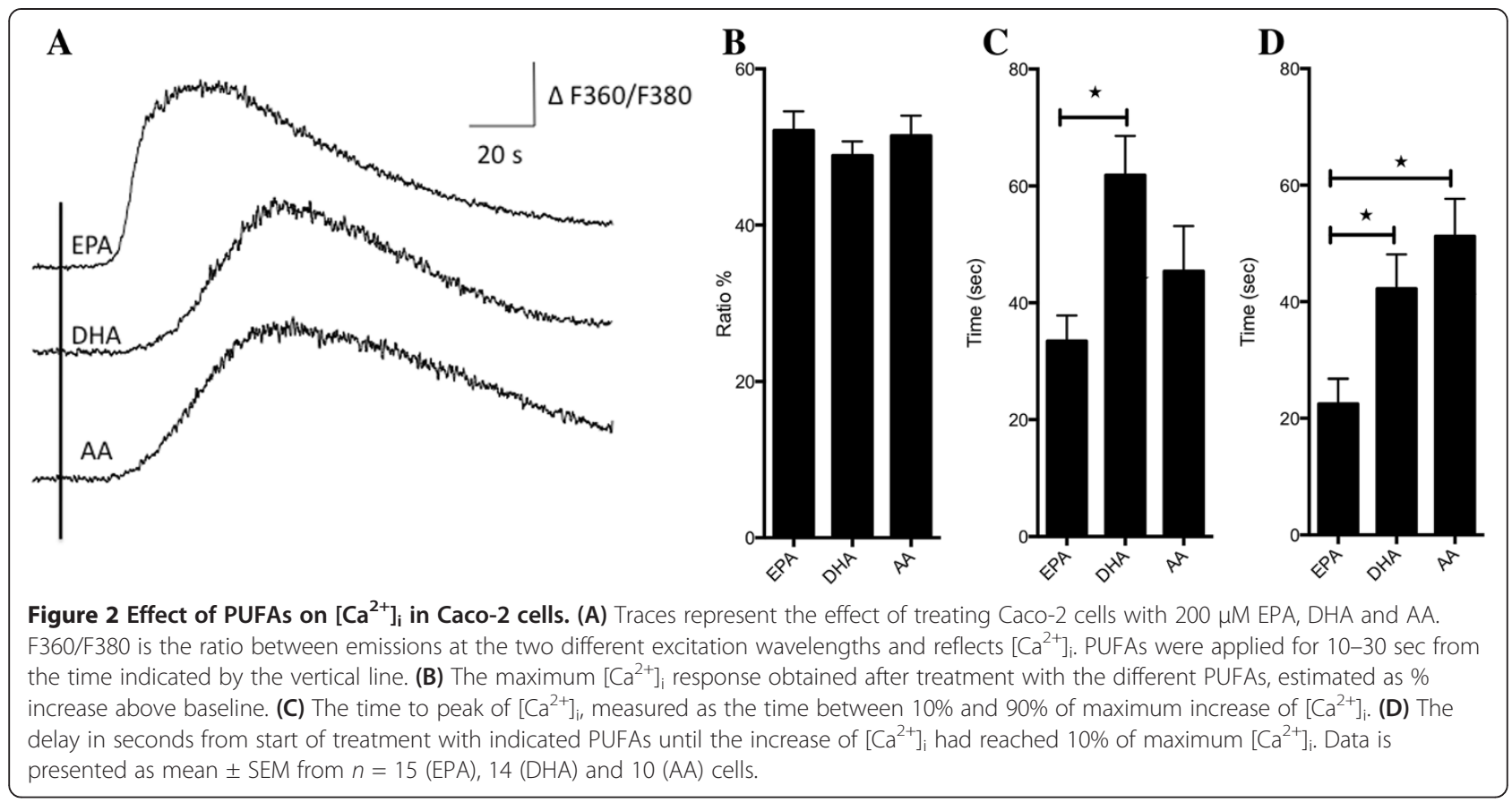

Figure $2 \mathrm{C}$ shows that the time to peak (defined as time from $10 \%$ to $90 \%$ of max F360/F380 ratio increase) of $\left[\mathrm{Ca}^{2+}\right]_{\mathrm{i}}$ during treatment with $200 \mu \mathrm{M}$ EPA was $33.4 \pm$ 4.4 sec, and significantly $(\mathrm{P}<0.05)$ faster than the time to peak of $\left[\mathrm{Ca}^{2+}\right]_{\mathrm{i}}$ after treatment with $200 \mu \mathrm{M}$ DHA which was $61.8 \pm 6.7 \mathrm{sec}$. The time to peak of $\left[\mathrm{Ca}^{2+}\right]_{\mathrm{i}}$ after treatment with $200 \mu \mathrm{M}$ AA was $45.4 \pm 7.7 \mathrm{sec}$, and was not significantly different from the time to peak of $\left[\mathrm{Ca}^{2+}\right]_{\mathrm{i}}$ after treatment with $200 \mu \mathrm{M}$ DHA or EPA.

The time from the start of treatment with the different PUFAs, until the increase in $\left[\mathrm{Ca}^{2+}\right]_{\mathrm{i}}$ started (defined as time from start of treatment to 10\% of max F360/F380 ratio increase), was also measured. Figure $2 \mathrm{D}$ shows that the delay after treatment $200 \mu \mathrm{M}$ EPA was $22.5 \pm 4.3$ sec, and significantly shorter compared to treatment with both $200 \mu \mathrm{M}$ DHA and $200 \mu \mathrm{M}$ AA. The delay after treatment with $200 \mu \mathrm{M}$ DHA and AA were $42.2 \pm$ $5.9 \mathrm{sec}$ and $51.2 \pm 6.4 \mathrm{sec}$ respectively.

\section{Activation of MAP kinase ERK1/2}

Since differences were observed in the ability of the PUFAs to enhance cytosolic $\mathrm{Ca}^{2+}$ - levels, we wanted to investigate whether such differences could also be detected in other signalling pathways. GPR120 is known to activate MAP kinase ERK1/2 in different cellular systems $[6,11,26]$, and we therefore investigated if triggering of GPR120 with EPA, DHA or AA would activate ERK1/ 2 in Caco- 2 cells. Figure 3A shows that treatment with $100 \mu \mathrm{M}$ EPA, DHA or AA in 20 min enhanced ERK1/2 activity significantly $(\mathrm{p}<0.5)$ in Caco- 2 cells. Interestingly, the activation induced by $100 \mu \mathrm{M}$ DHA at $20 \mathrm{~min}$ was stronger compared to treatment with EPA and AA, although not statistically significant using densitometry. Treatment with $100 \mu \mathrm{M}$ EPA or DHA resulted in similar kinetics in the activation of ERK1/2, while AA gave a slower response (Figure 3B).

GPCRs can activate MAP kinase ERK1/2 through different mechanisms. To scrutinize possible pathways involved in ERK1/2 activation induced by EPA, we used the PKA inhibitor H89, the Raf-1 inhibitor GW5074 and the EGF receptor inhibitor Gifitinib "Iressa". Pretreatment with $10 \mu \mathrm{M}$ H89 for $1 \mathrm{~h}$ before treatment with 100 $\mu \mathrm{M}$ EPA for $20 \mathrm{~min}$, did not affect ERK1/2 activation. However, pretreatment with $10 \mu \mathrm{M}$ GW5074 and 100 nM Iressa $1 \mathrm{~h}$ before treatment with $100 \mu \mathrm{M}$ EPA for 20 min, abolished ERK1/2 activity compared to treatment with $100 \mu \mathrm{M}$ EPA alone (Figure 3C).

\section{Anti-inflammatory properties of PUFAs}

GPR120 has been shown to inhibit NF- $\mathrm{KB}$ signalling induced by lipopolysaccharide (LPS) after binding to Toll-like receptor 4 (TLR4) on macrophages and adipocytes, due to binding of $\beta$-arrestin2 in complex with transforming growth factor- $\beta$-activated kinase- 1 (TAK1) and TAK1 binding protein-1 (TAB1) [11]. TLR4 and IL-1 receptor are members of the same superfamily and they use the same adaptors and kinases in their signalling pathways which lead to activation of NF-kB [27]. Since IL-1 $\beta$ is known to activate NF- $\mathrm{kB}$ signalling in Caco-2 cells [28], we investigated whether activation of GPR120 would influence IL-1 $\beta$ induced NF- $\kappa B$ activity in these cells. Treatment with $10 \mathrm{ng} / \mathrm{ml} \mathrm{IL-1} \beta$ for $30 \mathrm{~min}$ decreased IkB $\alpha$ 

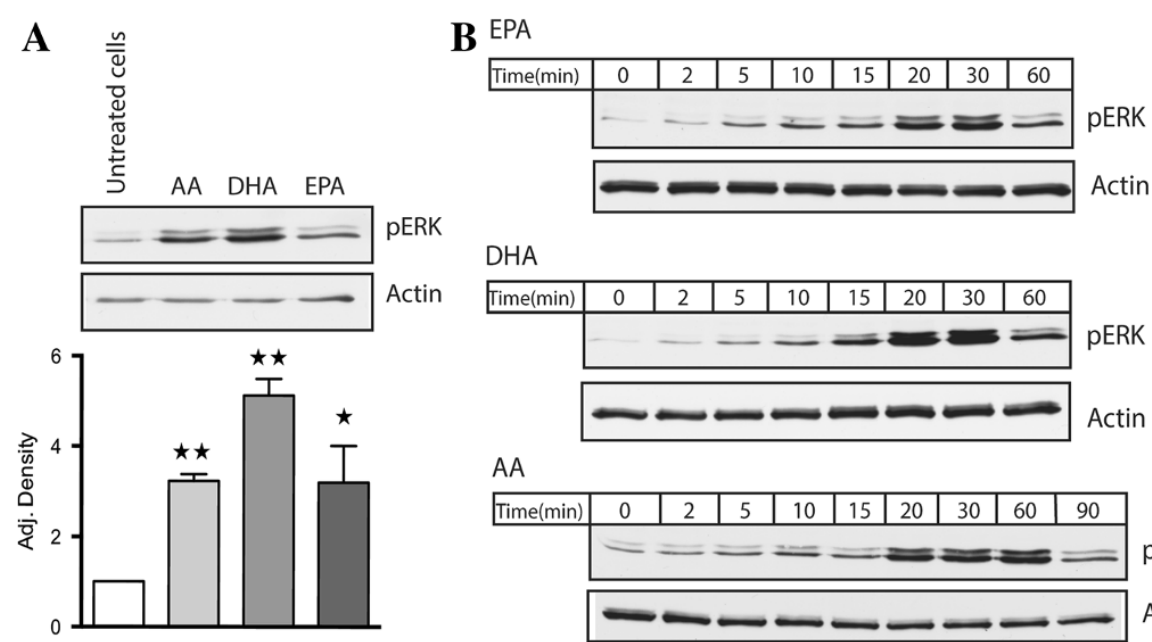

DHA

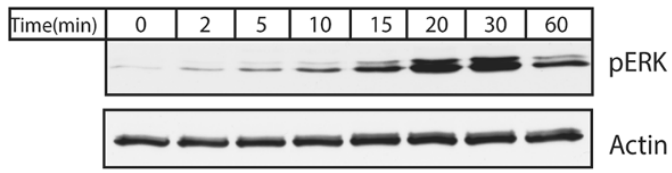

AA
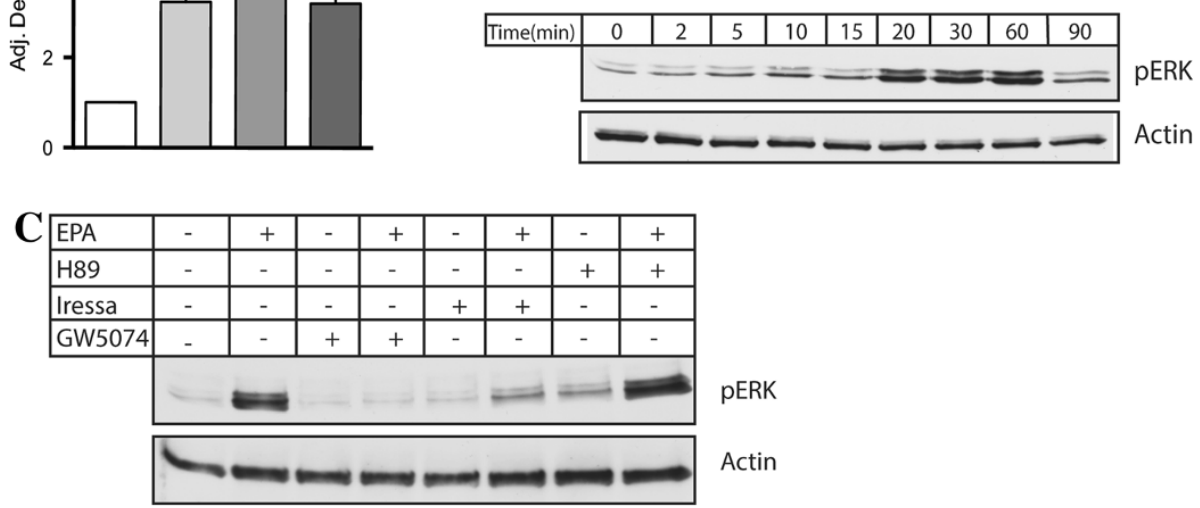

Figure 3 The effect of PUFAs on ERK1/2 activation in Caco-2 cells. (A) Cells were treated with $100 \mu \mathrm{M}$ EPA, DHA and AA for 20 min. Differences in pERK $1 / 2$ activity were determined using densitometry compared to untreated cells $\left(n=3,{ }^{*} p<0.05,{ }^{* *} p<0.01\right)$. (B) Cells were treated with $100 \mu \mathrm{M}$ EPA and DHA from 0-60 min, and $100 \mu \mathrm{M}$ AA from 0-90 min. (C) Cells were pretreated for $1 \mathrm{~h}$ with $10 \mu \mathrm{M} \mathrm{H89,10 \mu M}$ GW5074 and 100 nM Iressa before treatment with $100 \mu \mathrm{M}$ EPA for 20 min. The lysates were subjected to Western blotting to detect phosphorylated ERK1/2 and total actin. The figure is representative for at least three experiments with similar results.

expression in Caco-2 cells compared to untreated cells. Stimulation with EPA or AA, but not DHA, inhibited IL$1 \beta$ induced breakdown of IKB $\alpha$ significantly $(\mathrm{p}<0.05)$ compared to treatment with IL-1 $\beta$ alone. Even though the PUFAs inhibited IL-1 $\beta$ induced breakdown of IкB $\alpha$ with different efficiencies, these differences were not considered significant compared to each other (Figure 4A).

Since activation of MAP kinase ERK1/2 was dependent upon EGF receptor transactivation and Raf-1 activation, we tested whether these were involved in the ability of GPR120 to inhibit IL-1 $\beta$ induced breakdown of ІкB $\alpha$. Figure $4 \mathrm{~B}$ shows that neither Raf- 1 nor the EGF receptor are involved in the ability of EPA to inhibit IL-1 $\beta$ induced breakdown of IkB $\alpha$.

\section{Discussion}

Results from this study show that triggering of GPR120 with EPA, DHA or AA in Caco-2 cells activated three independent intracellular signalling events; accumulation of cytosolic $\mathrm{Ca}^{2+}$, EGF receptor- and Raf-1-dependent activation of MAP kinase ERK1/2, and EGF receptor- and Raf-1independent inhibition of IL-1 $\beta$ induced NF- $\mathrm{KB}$ activation. Interestingly, EPA, DHA and AA were able to activate these pathways with different kinetics and intensity.
The finding that GPR120 activates $G_{\alpha q}$ and the subsequent increase of cytosolic $\mathrm{Ca}^{2+}$ are in agreement with previous studies in other cellular systems $[6,11,25,29]$. In the first study to describe induction of GPR120 signalling by FFAs, EPA and DHA were shown to have almost equal ability to enhance $\left[\mathrm{Ca}^{2+}\right]_{\mathrm{i}}$ in HEK293 cells transfected with GPR120 [6]. Oh et al. (2010) used GPR120-transfected HEK293 cells to study accumulation of cytosolic $\mathrm{Ca}^{2+}$ after treatment with FFAs, and found that EPA and DHA enhanced $\left[\mathrm{Ca}^{2+}\right]_{\mathrm{i}}$ with same intensity. However, AA did not enhance $\left[\mathrm{Ca}^{2+}\right]_{\mathrm{i}}$ in this study [11]. We found that EPA, DHA and AA were all able to enhance $\left[\mathrm{Ca}^{2+}\right]_{\mathrm{i}}$ with the same efficiency, but with different kinetics. The finding that EPA was able to enhance $\left[\mathrm{Ca}^{2+}\right]_{\mathrm{i}}$ faster than DHA and AA may be due to differences in ligand affinity to GPR120 on Caco-2 cells.

The differences in $\mathrm{Ca}^{2+}$ signalling dynamics induced by the different PUFAs, did not correlate with the activation of pERK $1 / 2$ induced by the same PUFAs. AA induced a slower pERK 1/2 kinetic response than EPA and DHA. DHA gave strongest pERK $1 / 2$ activation after 20 min of treatment compared to AA and EPA, but these differences were not considered significant. We further show that the activation of pERK $1 / 2$ is a result of EGF 


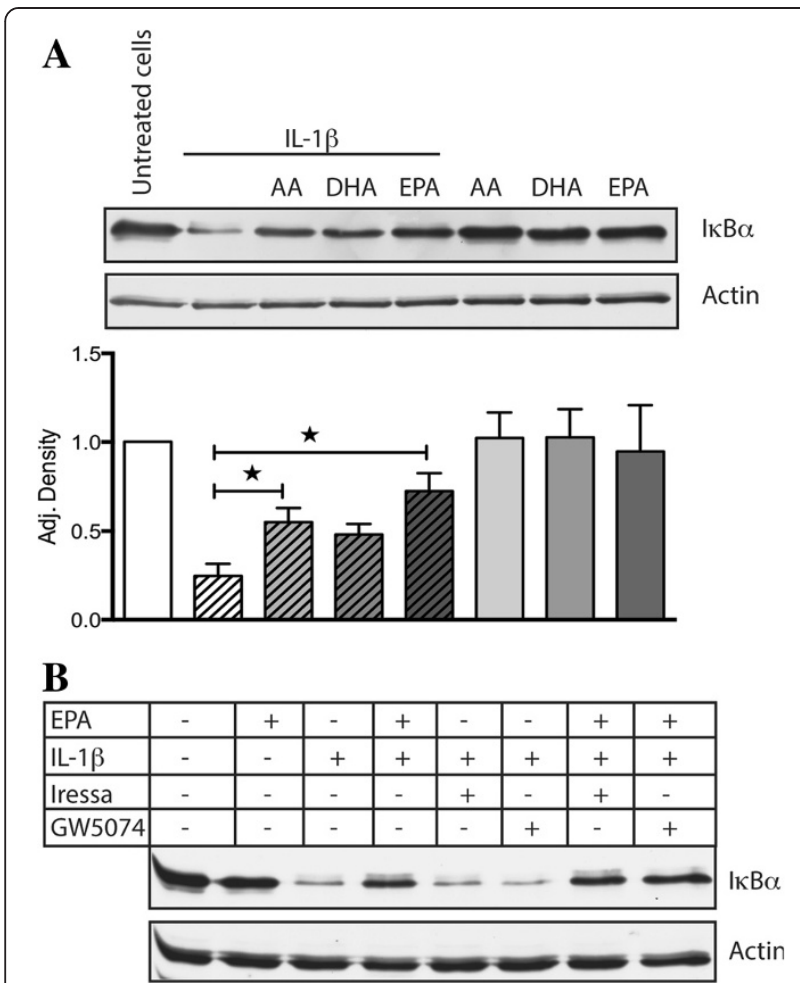

Figure 4 The effect of PUFAs on IL-1 $\beta$ induced degradation of IKBa in Caco-2 cells. (A) Cells were treated with $100 \mu \mathrm{M}$ EPA, DHA, AA for $1 \mathrm{~h}$, or with $100 \mathrm{ng} / \mathrm{ml} \mathrm{IL-1 \beta}$ for $30 \mathrm{~min}$, or with $100 \mu \mathrm{M}$ EPA, $\mathrm{DHA}, \mathrm{AA}$ for 1 hour and then treated with $100 \mathrm{ng} / \mathrm{ml} \mathrm{IL-1 \beta}$ for 30 min. Differences in $1 k B a$ expression were determined using densitometry and compared to untreated cells $\left(n=3,{ }^{*} p<0.05\right)$. (B) Cells were pretreated with $10 \mu \mathrm{M}$ GW5074 and $100 \mathrm{nM}$ Iressa for $1 \mathrm{~h}$ before treatment with $100 \mu \mathrm{M}$ EPA for $1 \mathrm{~h}$ and then treated with $100 \mathrm{ng} / \mathrm{ml} \mathrm{IL-1 \beta}$ for $30 \mathrm{~min}$. Cells were also treated with only $100 \mu \mathrm{M}$ EPA, $10 \mu \mathrm{M}$ GW5074 and $100 \mathrm{nM}$ Iressa for $1 \mathrm{~h}$ and $100 \mathrm{ng} /$ $\mathrm{ml} \mathrm{IL-1 \beta}$ for $30 \mathrm{~min}$. The lysates were subjected to Western blotting to detect total IkBa and actin. The figure is representative for at least three experiments with similar results.

receptor transactivation involving Raf-1 kinase. Longchain PUFAs are known to activate EGF receptor in other cellular systems [30,31], but this activation has not been linked to GPR120. In the present study, we show that pretreatment with the EGF receptor specific inhibitor Iressa, and Raf-1 inhibitor GW5074 abolish ERK1/2 activation induced by EPA. Raf- 1 is a crucial kinase in the MAP kinase signalling cascade leading to activation of ERK1/2. EGF receptor can activate the Ras-Raf-Mek cascade through the activation of Grb2 and SOS. The finding that PKA inhibitor H89 did not influence ERK1/2 activity is in line with previous studies describing GPR120 signalling, where no study has reported activation of PKA after GPR120 activation.

Both cytosolic $\mathrm{Ca}^{2+}$ increase and pERK1/2 activation are involved in GPR120-induced secretion of GLP-1 and CCK from intestinal cells $[6,10,32,33]$. The findings that these pathways are activated differently by EPA, DHA and AA in Caco-2 cells might gain new insights into variations in the different PUFAs ability to induce the secretion of GLP-1 and CCK.

Increased dietary intake of omega-6 PUFAs, and a lower dietary intake of omega-3 PUFAs are though to contribute to the development of IBD $[34,35]$. There is clear evidence that omega-6 PUFAs exert pro-inflammatory events compared to omega-3 PUFAs [34]. However, our results suggest that both omega- 3 and omega- 6 PUFAs exert the same anti-inflammatory effects by inhibiting NF- $\mathrm{kB}$ activity after binding GPR120 on Caco- 2 cells. DHA, EPA and AA were all able to inhibit IL- $1 \beta$ induced breakdown of $\mathrm{I} \kappa \mathrm{B} \alpha$, but EPA and AA mediated the strongest inhibitory effects. Since this effect was independent of Raf-1 and EGF receptor, we speculate whether GPR120 may inhibit IL-1 $\beta$ signalling in the same manner as TLR4 signalling. These findings challenge the view that only omega-3 PUFAs exert anti-inflammatory effects after binding GPR120. Our results may also be important in the understanding of how long-chain PUFAs, not only omega-3 PUFAs influence the inflammatory response in patients with IBD.

In conclusion, our results show that both omega- 3 and omega-6 PUFAs activate the same GPR120-mediated signalling events in Caco- 2 cells, but differences regarding intensity and kinetics were observed. Previously, antiinflammatory effects of GPR120 have only been linked to omega-3 PUFAs. We show, for the first time that they might be linked to both omega- 3 and omega- 6 PUFAs.

\section{Materials and methods}

\section{Materials}

Sodium salts of arachidonic acid, docosahexaenoic acid and eicosapentaenoic acid were from Sigma-Aldrich. Antibodies targeted against Phospho-p44/42 MAPK (ERK1/2) and $I_{\kappa} \mathrm{B} \alpha$ were from Cell Signaling Technology and the antibody targeted against $\alpha$-actin was from Sigma-Aldrich. HRP-conjugated secondary antibodies, Goat Anti-Mouse IgG $(\mathrm{H}+\mathrm{L})$ and Goat Anti-Rabbit IgG $(\mathrm{H}+\mathrm{L})$ were from Southern Biotech. Other chemicals used were: H89 from Alexis Chemicals, GW5074 from Sigma-Aldrich and Gefinib "Iressa” from Selleck Chemicals LLC.

\section{Cell culture}

The human colon adenocarcinoma cell line Caco-2 (ATTC; HTG-37 ${ }^{\mathrm{TM}}$ ) were grown in RPMI-1640 supplemented with $10 \%$ fetal calf serum (FCS), $100 \mu \mathrm{M}$ non-essential amino acids, $1 \mathrm{mM}$ sodium pyruvate (all from PAA Laboratories), and gentamicin (24 mg/l) (Lonza). Cells were maintained in a humidified incubator at $37^{\circ} \mathrm{C}$ and $5 \% \mathrm{CO}_{2}$. 


\section{PCR}

RNA from both tissue and cells were isolated using Qiagen RNase Mini kit (Qiagen). Complementary DNA (cDNA) was synthesized with Super Script ${ }^{\circledR}$ Vilo $^{\text {TM }}$ (Applied Biosystems) using $20 \mu \mathrm{l}$ of reaction mixture containing 2 $\mu g$ RNA. PCR was set up using TaqMan ${ }^{\circledR}$ Master Mix and TaqMan $^{\circledR}$ probes: GPR120 (Hs00699184_m1), GPR40 (Hs03045166_s1) and rplp0 (Hs99999902_m1). 50 ng template was used in each reaction.

\section{Cytosolic $\mathrm{Ca}^{2+}$ measurements}

Measurements of the cytosolic $\mathrm{Ca}^{2+}$ concentration were performed in the following extracellular solution (EC): $150 \mathrm{mM} \mathrm{NaCl}, 5 \mathrm{mM} \mathrm{KCl}, 2.4 \mathrm{mM} \mathrm{CaCl}_{2}, 1.3 \mathrm{mM}$ $\mathrm{MgCl}_{2}, 10 \mathrm{mM}$ glucose and $10 \mathrm{mM}$ HEPES, adjusted to pH 7.4 by $\mathrm{NaOH}$.

Approximately $10^{6}$ Caco- 2 cells were seeded out in collagen-coated glass-bottom dishes (MatTek Coorporation) 3-4 days prior to experiment. Cells were loaded with $5 \mu \mathrm{M}$ of the fluorescent $\mathrm{Ca}^{2+}$ indicator fura-2/AM (Molecular Probes) in EC for $45 \mathrm{~min}$ at $37^{\circ} \mathrm{C}$, followed by washout of the fura- 2 ester and further 30 min incubation at room temperature. Then, cells were mounted on an Olympus OSP-3 system for dual excitation fluorometry (Olympus). The excitation light was switched at $200 \mathrm{~Hz}$ between 360 and $380 \mathrm{~nm}$ using a rotating mirror. The emitted fluorescence was recorded at $510 \mathrm{~nm}$ with a photomultiplier, and the measurements were restricted to single cells by a pinhole diaphragm. The ratio between emissions at the two different excitation wavelengths (F360/F380) reflects the cytosolic $\mathrm{Ca}^{2+}$ concentration $\left[\mathrm{Ca}^{2+}\right]_{\mathrm{i}}$. In the present study, the relative increase in $\left[\mathrm{Ca}^{2+}\right]_{\mathrm{i}}$ is used as a measure of the response to the PUFAs. Therefore, calibration in order to determine the absolute $\mathrm{Ca}^{2+}$ concentrations was not performed. Cells were exposed to the different PUFAs by pressure ejection (about $1 \mathrm{kPa}$ ) from a micropipette placed about $40 \mu \mathrm{m}$ from the cell. As negative control, cells were exposed to EC by pressure ejection using the same conditions as described above. No artefacts were observed when ejecting normal EC onto cells, and the increase in $\left[\mathrm{Ca}^{2+}\right]_{\mathrm{i}}$ was compared to untreated cells.

\section{Cell stimulation and lysis}

Sodium salts of DHA, EPA and AA were dissolved in autoclaved deionized water and further diluted in RPMI 1640. $0.5 \times 10^{6}$ cells were seeded per well in a 24-well plate. The day after, the cells were serum-starved for 24 $\mathrm{h}$ in RPMI-1640 supplemented with 1\% FCS, and then stimulated as indicated. After stimulation, the cells were lysed in $100 \mu \mathrm{l}$ lysis buffer (25 mM Tris, pH7.5, 1\% NP40, $100 \mathrm{mM} \mathrm{NaCl}, 20 \mathrm{mM} \mathrm{NaF}, 1 \mathrm{mM}$ orthovanadate, $1 \mu \mathrm{g} / \mathrm{ml}$ leupeptin, $1 \mu \mathrm{g} / \mathrm{ml}$ antipain, $1 \mu \mathrm{g} / \mathrm{ml}$ pepstatin A and $1 \mu \mathrm{g} / \mathrm{ml}$ chymostatin )per well for $30 \mathrm{~min}$ at $4^{\circ} \mathrm{C}$.
Lysates were spun at $4^{\circ} \mathrm{C}$ for $15 \mathrm{~min}$ at $15000 \mathrm{rpm}$, and the supernatants were used for Western blotting.

\section{Western blotting}

Cell lysates were electrophoresed in 10\% SDSpolyacrylamide gels. The separated proteins were transferred to PVDF membranes by Western blotting. Upon blotting, the membranes were blocked with 5\% non-fat dry milk for $1 \mathrm{~h}$, and probed with specific antibodies to detect protein of interest. Luminata ${ }^{\mathrm{TM}}$ Crescendo Western HRP Substrate (Merck Millipore) was used as substrate for HRP-conjugated secondary antibodies, and the membranes were exposed using X-Ray film (Pierce). Densitometry analysis was performed using Image J 1.46r. Adj. density was obtained by comparing the intensity of the band of interest with the intensity of the actin band from the same sample.

\section{Competing interests}

There are no conflicts of interest to declare.

\section{Authors' contributions}

K.M was involved in the experimental procedures, data analysis and writing of the manuscript. T.M.H was involved in the cytosolic $\mathrm{Ca}^{2+}$ measurements, and writing of the manuscript. C.R.K. and T.L contributed to the writing of the manuscript. T.L. supervised the project. All authors read and approved the final manuscript.

\section{Acknowledgements}

The present study was supported by The Norwegian University of Life Sciences. We would like to thank Professor Olav Sand at the University of Oslo, who kindly provided equipment for the $\mathrm{Ca}^{2+}$ measurements.

\section{Author details}

${ }^{1}$ Department of Chemistry, Biotechnology and Food Science, University of Life Sciences, Post box 5003, NO-1430 Aas, Norway. ${ }^{2}$ Department of Biosciences, University of Oslo, NO-0316 Oslo, Norway. ${ }^{3}$ Quality and Research Department, Ostfold Hospital Trust, NO-1603 Fredrikstad, Norway.

Received: 5 April 2013 Accepted: 8 July 2013

Published: 13 July 2013

\section{References}

1. Le Poul E, Loison C, Struyf S, Springael JY, Lannoy V, Decobecq ME, Brezillon S, Dupriez V, Vassart G, Van Damme J, et al: Functional characterization of human receptors for short chain fatty acids and their role in polymorphonuclear cell activation. J Biol Chem 2003, 278:25481-25489.

2. Nilsson NE, Kotarsky K, Owman C, Olde B: Identification of a free fatty acid receptor, FFA2R, expressed on leukocytes and activated by short-chain fatty acids. Biochem Biophys Res Commun 2003, 303:1047-1052.

3. Briscoe CP, Tadayyon M, Andrews JL, Benson WG, Chambers JK, Eilert MM, Ellis C, Elshourbagy NA, Goetz AS, Minnick DT, et al: The orphan G protein-coupled receptor GPR40 is activated by medium and long chain fatty acids. J Biol Chem 2003, 278:11303-11311.

4. Itoh Y, Kawamata Y, Harada M, Kobayashi M, Fujii R, Fukusumi S, Ogi K, Hosoya $M$, Tanaka $Y$, Uejima $H$, et al: Free fatty acids regulate insulin secretion from pancreatic beta cells through GPR40. Nature 2003, 422:173-176.

5. Kotarsky K, Nilsson NE, Flodgren E, Owman C, Olde B: A human cell surface receptor activated by free fatty acids and thiazolidinedione drugs. Biochem Biophys Res Commun 2003, 301:406-410.

6. Hirasawa A, Tsumaya K, Awaji T, Katsuma S, Adachi T, Yamada M, Sugimoto Y, Miyazaki S, Tsujimoto G: Free fatty acids regulate gut incretin glucagon-like peptide-1 secretion through GPR120. nature medicine 2005, 11:90-94. 
7. Latour MG, Alquier T, Oseid E, Tremblay C, Jetton TL, Luo J, Lin DC, Poitout $\mathrm{V}$ : GPR40 is necessary but not sufficient for fatty acid stimulation of insulin secretion in vivo. Diabetes 2007, 56:1087-1094.

8. Steneberg P, Rubins N, Bartoov-Shifman R, Walker MD, Edlund H: The FFA receptor GPR40 links hyperinsulinemia, hepatic steatosis, and impaired glucose homeostasis in mouse. Cell Metab 2005, 1:245-258.

9. Edfalk S, Steneberg P, Edlund H: Gpr40 is expressed in enteroendocrine cells and mediates free fatty acid stimulation of incretin secretion. Diabetes 2008, 57:2280-2287.

10. Tanaka T, Katsuma S, Adachi T, Koshimizu TA, Hirasawa A, Tsujimoto G. Free fatty acids induce cholecystokinin secretion through GPR120. Naunyn Schmiedebergs Arch Pharmacol 2008, 377:523-527.

11. Oh DY, Talukdar S, Bae EJ, Imamura T, Moringa H, Fan W, Li P, Lu WJ, Watkins SM, Olefsky JM: GPR120 is an Omega-3 fatty acid receptor mediating potent anti-inflammatory and insulin-sensitizing effects. Cell 2010, 142:687-698.

12. Zapata-Gonzalez F, Rueda F, Petriz J, Domingo P, Villarroya F, Diaz-Delfin J, de Madariaga MA, Domingo JC: Human dendritic cell activities are modulated by the omega-3 fatty acid, docosahexaenoic acid, mainly through PPAR(gamma):RXR heterodimers: comparison with other polyunsaturated fatty acids. J Leukoc Biol 2008, 84:1172-1182.

13. Kong W, Yen JH, Vassiliou E, Adhikary S, Toscano MG, Ganea D: Docosahexaenoic acid prevents dendritic cell maturation and in vitro and in vivo expression of the IL-12 cytokine family. Lipids Health Dis 2010, 9:12.

14. Vilaseca J, Salas A, Guarner F, Rodriguez R, Martinez M, Malagelada JR: Dietary fish oil reduces progression of chronic inflammatory lesions in a rat model of granulomatous colitis. Gut 1990, 31:539-544.

15. Nieto N, Torres Ml, Rios A, Gil A: Dietary polyunsaturated fatty acids improve histological and biochemical alterations in rats with experimental ulcerative colitis. J Nutr 2002, 132:11-19.

16. Hudert CA, Weylandt KH, Lu Y, Wang J, Hong S, Dignass A, Serhan CN, Kang JX: Transgenic mice rich in endogenous omega-3 fatty acids are protected from colitis. Proc Natl Acad Sci U S A 2006, 103:11276-11281.

17. Shoda R, Matsueda K, Yamato S, Umeda N: Therapeutic efficacy of N-3 polyunsaturated fatty acid in experimental Crohn's disease. J Gastroenterol 1995, 30(Suppl 8):98-101.

18. Yuceyar H, Ozutemiz O, Huseyinov A, Saruc M, Alkanat M, Bor S, Coker I, Batur $Y$ : Is administration of $n-3$ fatty acids by mucosal enema protective against trinitrobenzene-induced colitis in rats? Prostaglandins Leukot Essent Fatty Acids 1999, 61:339-345.

19. Andoh A, Tsujikawa T, Ishizuka I, Araki Y, Sasaki M, Koyama S, Fujiyama Y: $\mathrm{N}-3$ fatty acid-rich diet prevents early response of interleukin- 6 elevation in trinitrobenzene sulfonic acid-induced enteritis. Int J Mol Med 2003, 12:721-725.

20. Cabre E, Manosa M, Gassull MA: Omega-3 fatty acids and inflammatory bowel diseases - a systematic review. Br J Nutr 2012, 107(Suppl 2):S240-252.

21. Ramakers JD, Mensink RP, Schaart G, Plat J: Arachidonic acid but not eicosapentaenoic acid (EPA) and oleic acid activates NF-kappaB and elevates ICAM-1 expression in Caco-2 cells. Lipids 2007, 42:687-698.

22. Marion-Letellier R, Butler M, Dechelotte P, Playford RJ, Ghosh S: Comparison of cytokine modulation by natural peroxisome proliferator-activated receptor gamma ligands with synthetic ligands in intestinal-like Caco-2 cells and human dendritic cells-potential for dietary modulation of peroxisome proliferator-activated receptor gamma in intestinal inflammation. Am J Clin Nutr 2008, 87:939-948.

23. Im DS: Omega-3 fatty acids in anti-inflammation (pro-resolution) and GPCRs. Prog Lipid Res 2012, 51:232-237.

24. Osborn O, Olefsky JM: The cellular and signaling networks linking the immune system and metabolism in disease. Nat Med 2012, 18:363-374.

25. Tanaka T, Yano T, Adachi T, Koshimizu TA, Hirasawa A, Tsujimoto G: Cloning and characterization of the rat free fatty acid receptor GPR120: in vivo effect of the natural ligand on GLP-1 secretion and proliferation of pancreatic beta cells. Naunyn Schmiedebergs Arch Pharmacol 2008, 377:515-522.

26. Katsuma S, Hatae N, Yano T, Ruike Y, Kimura M, Hirasawa A, Tsujimoto G: Free fatty acids inhibit serum deprivation-induced apoptosis through GPR120 in a murine enteroendocrine cell line STC-1. J Biol Chem 2005, 280:19507-19515.

27. Medzhitov R: Toll-like receptors and innate immunity. Nat Rev Immunol 2001, 1:135-145.

28. Al-Sadi R, Ye D, Said HM, Ma TY: IL-1beta-induced increase in intestinal epithelial tight junction permeability is mediated by MEKK-1 activation of canonical NF-kappaB pathway. Am J Pathol 2010, 177:2310-2322.
29. Hara T, Hirasawa A, Sun Q, Sadakane K, Itsubo C, Iga T, Adachi T, Koshimizu TA, Hashimoto T, Asakawa Y, Tsujimoto G: Novel selective ligands for free fatty acid receptors GPR120 and GPR40. Naunyn Schmiedebergs Arch Pharmacol 2009, 380:247-255.

30. Soto-Guzman A, Robledo T, Lopez-Perez M, Salazar EP: Oleic acid induces ERK1/2 activation and AP-1 DNA binding activity through a mechanism involving Src kinase and EGFR transactivation in breast cancer cells. Mol Cell Endocrinol 2008, 294:81-91.

31. Vacaresse N, Lajoie-Mazenc I, Auge N, Suc I, Frisach MF, Salvayre R, Negre-Salvayre A: Activation of epithelial growth factor receptor pathway by unsaturated fatty acids. Circ Res 1999, 85:892-899.

32. Adachi T, Tanaka T, Takemoto K, Koshimizu TA, Hirasawa A, Tsujimoto G: Free fatty acids administered into the colon promote the secretion of glucagon-like peptide-1 and insulin. Biochem Biophys Res Commun 2006, 340:332-337.

33. Shah BP, Liu P, Yu T, Hansen DR, Gilbertson TA: TRPM5 is critical for linoleic acid-induced CCK secretion from the enteroendocrine cell line, STC-1. Am J Physiol Cell Physiol 2012, 302:C210-219.

34. Simopoulos AP: The importance of the ratio of omega-6/omega-3 essential fatty acids. Biomed Pharmacother 2002, 56:365-379.

35. Shoda R, Matsueda K, Yamato S, Umeda N: Epidemiologic analysis of Crohn disease in Japan: increased dietary intake of $n-6$ polyunsaturated fatty acids and animal protein relates to the increased incidence of Crohn disease in Japan. Am J Clin Nutr 1996, 63:741-745.

doi:10.1186/1476-511X-12-101

Cite this article as: Mobraten et al:: Omega-3 and omega-6 PUFAs induce the same GPR120-mediated signalling events, but with different kinetics and intensity in Caco-2 cells. Lipids in Health and Disease $201312: 101$

\section{Submit your next manuscript to BioMed Central and take full advantage of:}

- Convenient online submission

- Thorough peer review

- No space constraints or color figure charges

- Immediate publication on acceptance

- Inclusion in PubMed, CAS, Scopus and Google Scholar

- Research which is freely available for redistribution 